\title{
The Entrepreneurial Finance and the Issue of Funding Startup Companies
}

\section{Dr. Achibane Mustapha}

Doctor in Economic Sciences, Head of the Department of business and management, National School of Commerce and management of Kenitra, University IbnToufail, Faculty of Legal Sciences, economic and social Kenitra, Morocco

\section{Jamal Tlaty}

$\mathrm{PhD}$ student in sciences of management, national school of Commerce and management of Kenitra, University IbnToufail, Faculty of Legal Sciences, economic and social studies- Kenitra, Morocco

Doi: 10.19044/esj.2018.v14n13p268 URL:http://dx.doi.org/10.19044/esj.2018.v14n13p268

\begin{abstract}
The emergence of entrepreneurial finance as a research field is the result of a double interest from both entrepreneurship researchers and financiers. Indeed, researchers focus on the financial fact existing in all entrepreneurial projects, while financiers consider that entrepreneurial situations have specific features that we should lean on.

Our article is a presentation of the basic mechanisms of the entrepreneurial Finance, and its relationship with the entrepreneurial venture in its early stages; it will also focus on the theoretical aspect on both the Agency theory and its developments, as well as on the emerging organization that takes into account the evolution of the Startups reality. Finally, we will make a presentation of the different modes of financing Startups.

Our report reveals that little work was spent on funding the very beginnings of the entrepreneurial venture. To this end, the Finance business tends to stand out from the corporate finance by different concepts and new issues, including the notions of startup, TPE or ' gazelles', that are frequently used at the expense of the notion of firms or groups.
\end{abstract}

Keywords: Finance business, Startup companies, business angels, start-up, TPE.

\section{Introduction:}

The emergence of entrepreneurial finance as a research field is the result of a double interest from both researchers in entrepreneurship and 
financiers. Researchers in entrepreneurship focus on the financial fact that exists in each entrepreneurial project. Financiers, on the other hand, consider that entrepreneurial situations have specific features we should lean on.

From the point of view of finance researchers, according to Denis (2004), entrepreneurship has long been regarded as a field that is totally separated from corporate finance; this has been said based on the assumption that the issues encountered in entrepreneurial finance are sufficiently different from those encountered in listed companies.

However, financiers have recently acknowledged that entrepreneurial situations are characterised by the same two fundamental issues, which are basic to the financial theory: agency problems and information asymmetry.

Entrepreneurial finance differs from traditional corporate finance only in the fact that the importance of these issues is highly important, which requires separate contractual solutions different from those put in place in bigger and more mature companies.

\section{The issue}

Will our problem be about the financing of Start-ups in general, or about funding in the beginning of the entrepreneurial venture? We will study the different sources of funding (Bank, Angel business, private equity, LBO etc...); we will also explore the role of business angels, through emphasising on the financial specificities of some atypical companies in terms of the neoclassical financial framework, such as the TPE and SMEs.

This article is a part of various management studies that could be used to understand and analyse Start-Ups financing methods, as well as the motivations of entrepreneurs to cross the entrepreneurial risk with the financial risk.

\section{Section 1: Entrepreneurship and the entrepreneurial process}

Stevenson (1989) defines entrepreneurship as being "the process that brings people to consider owning a business as an option or a solution of viable career, to create business projects, to learn how to become an entrepreneur and to launch and grow a business.

\section{Sub-section 1: Entrepreneurial foundations and development process}

In this section, we will present the various models of entrepreneurship, its basic theories, as well as the entrepreneurial process.

\section{A - Models of entrepreneurship}

The entrepreneurship study has been done through three major phases; early studies focused on the entrepreneur himself, on his psychological characteristics and on the profile of the successful creator, it is the 
fundamentalist approach. The contingent approach, on the other hand, links efficiency with the adaptation and coherence of the concept and the situation; universal solutions no longer exist, there are only solutions that are appropriate to the situations' characteristics. Recent studies focus on the analyse of entrepreneurship from a procedural perspective.

We will briefly present these three approaches to ultimately lead to a global model that brings the different theories together.

\section{Fundamentalism}

The first studies focus on the traits of the Entrepeneur and his characteristics. These studies correspond to what the Americans call 'The line approach'. Later on, several authors will include other variables and offer more complex patterns, such as the Shapero model (1975).

\section{" The trait approach."}

Entrepreneurs are born creators. They are born with a sixth sense, an intuitive ability to undertake and achieve spectacular actions.

The entrepreneur has values (leadership, sense of responsibility, autonomy), and posesses attitudes (risk-taking, initiative), or needs such as the need of freedom, realization and of recognition...

a) The need of achievement, the desire of professional fulfilment

In a contemporary society where one is forced to always give the best to stand out, the future entrepreneur is seeking social recognition and personal fulfillment.

b)The financial perspectives and the construction of an heritage ${ }^{[1]}$ Statistics show that the incomes of entrepreneurs are substantially higher than those of employees. Beyond the financial perspective in the short term, the contractor can build long-term wealth.

\section{c) The need of autonomy}

According to Davids (1963), the need for autonomy is manifested in individuals who prefer to set up their own objectives in the first place, to develop action plans and personally take control of their achievements in the second place. This desire for autonomy is generally found in the entrepreneur who has spent several years in the service of a company.

\section{d)The passion to develop my own idea}

The idea is personal, and the individual with the idea is the most respected ; he has the legitimacy of being highly credited in society...

\section{e)'Locus of Control'}

Different studies have focused on this concept ; the individual has the feeling that he could influence what would happen by his conduct and behaviour; He feels power and a strong self-confidence, pushing him to act and dig his way to the path of success. 


\section{(f) the propensity to risk-taking}

Entrepreneurs accept taking risks. For Belley (1990), these risks are of different natures, and emerge in different times and in an unpredictable manner.

This respectively consists in the financial risk of getting a mortgage on a local as with a security deposit and in having a professional loan. The professional risk itself consists in leaving an actual jobposition in order to create a new business, by giving up on an insured situation, and by facing the unknown.

\section{B - The model of SHAPERO}

It is a well-known model dating back to 1975, that was often restated and commented by other authors (Lacasse, Lacasse and Lambert, Neunreuther, Sweeney) ; it was finally completed and enriched (Belley 1989 and 1990). According to Shapero, entrepreneurship is a multidimensional phenomenon, that needs, in order to be analyzed, to take into account, in addition to the psychological characteristics of the entrepreneur, a number of contextual factors classified under three types : discontinuity, credibility and the feasibility.

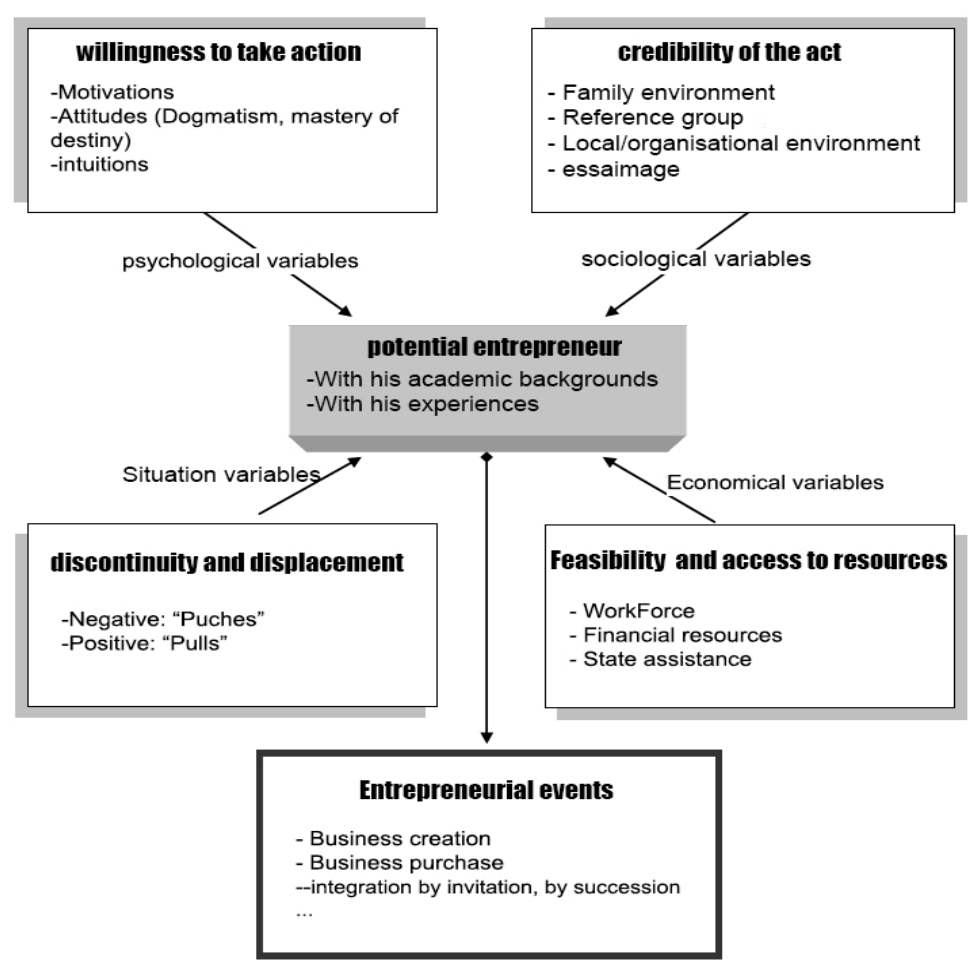

Figure 1: The model of Shapero 
In addition to his own personality, which is called the psychological variable, three other variables, sociological, economic and of status, affect the potential entrepreneur and lead the entrepreneurial event to trigger.

\section{(j) Review of the SHAPERO model}

Despite the importance of the three new variables cited by Shapero, this model was sometimes criticized by researchers who found that it does not emphasize an important dimension, which is the opportunity. According to G.P Sweeney, "the term of entrepreneurs applies to the people who transform events into opportunities".

\section{Sub-section 2: The entrepreneurial process}

From the 1990s onward, and based on the findings about the failure of the ' related approach', most entrepreneurship studies aimed to study the behavior of the entrepreneur in the creation process.

\section{A - The entrepreneurial behaviour}

To analyse the phenomenon of entrepreneurship, we will try to explain the theory of "Organizational Behaviour", which focuses on the relationships between individuals and organizations, as well as on the inter-individual or inter-group connections within organizations.

This is oriented around four major themes:

The commitment of the individual towards the action and the Organization (concepts of motivation, of involvement).

The 'fit' of the individual in the organization (information exchange, learning within the Organization, the confrontation of values),

The dynamics of leadership, and finally

interpersonal and inter-group relations.

David B. Greenberger and Donald L. Sexton offer an interactive model of creating a company as the result of an interaction between a number of factors, including entrepreneurial spirit, personality traits, self-knowledge, social support and status variables.

The interaction model is schematized as following:

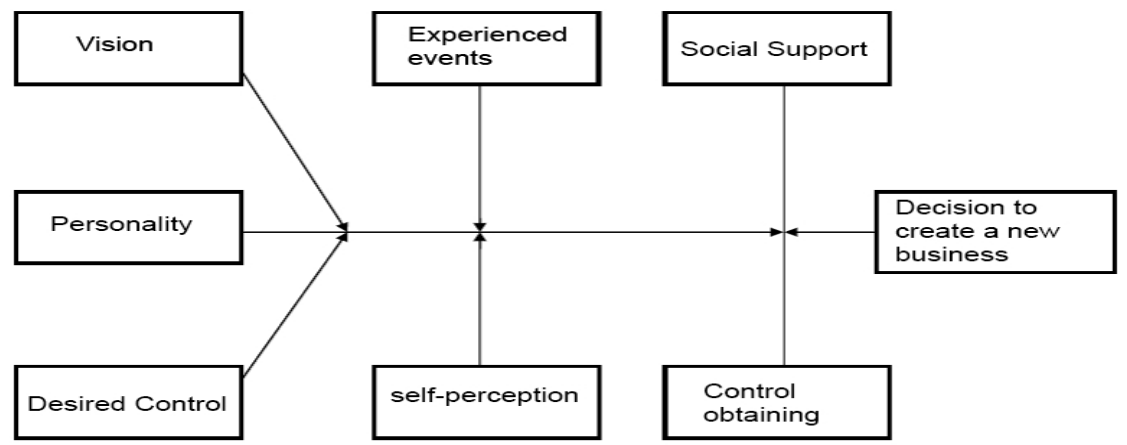




\section{Interactif model of entrepreunal behaviour according to D. Greenberger et D. Sexton}

This model has three main links used as catalyst in identifying a new opportunity of business creation.

Then four other factors influence the effect of catalysts on individual decisions, which will help converting an individual from a No-Creator to a Creator state.

Finally, the third component is the probability that an individual has to create a new business.

\section{B - Entrepreneurial behaviour, an entreprise behavior}

Jeffrey G. Covin and Dennis P. Slevin have evetually offered a conceptual model of entrepreneurship as a phenomenon of an organizational origin. This model focuses on the origins and the consequences of an entrepreneurial attitude, as well as on the variables influencing relationships between the entrepreneurial attitude and the performance of the firm.

\section{Section 2: Theoretical foundations of entrepreneurial finance Sub-section 1: The Agency theory}

The Agency theory stands as a paradigm that allows us to explain the relationship between the Agent and the Principal, it discusses the implications of separating the financial ownership and the control (Jensen and Meckling, 1976).

On the other hand, the agency costs are not identical at each stage of the creation and of the development of the company. We examine two periods: before and after the investment. The probability of having agency costs seems to have higher importance in the pre- investment phase than in the postinvestment one.

\section{-before the investment:}

During this period, the objectives of the two parties may be divergent; the investor is focused on the process of "due diligence" in order to get things right, while the contractor's main goal is the success of his company.

\section{-After the investment:}

The agency risks seem to be more limited during this phase. If the investor has made his decision, it means that he is convinced that both the entrepreneur and the project are interesting. In order to limit the risks, he will implement, through shareholder's agreement, many control procedures.

The Agency theory seems more limited during the post-investment period, and is more centred around the investor and less around the motivations and the vision of the contractor for its project.

Another reason that can explain the use of incomplete contracts theory is related to the information asymmetry. 
The Agency theory therefore seems insufficient to accurately explain the E-Irelationship (entrepreneur and investor). Could the theory of stewardship fill the gaps in the Agency theory and explain this relationship more accurately?

\section{The stewardship theory as an alternative to the Agency theory:}

It is tempting to try to explain the E-Irelationship using the stewardship theory (Davis, Sam \& Donaldson, 1997; Donaldson \& Davis 1991), and to notice if it fills the gaps previously observed, especially in the post-investment phase. It represents an antithetical approach to the Agency theory, by identifying the steward a bit as the opposite of the agent. Instead of trying to "betray" the principal, as an agent is suspected of, the intendant adopts a behaviour that focuses on the organization, in a way that helps him to improve performances and meet the principal's expectations; he might even promote the interests of the company to the detriment of his personal interests. The Intendant maximizes his utility function when his objectives are converging with those of the principal.

The entrepreneur and investor are both seeking the success of the business, but they can differ on the way to achieve this goal.

Stewardship theory also seems unable to precisely define the E-I relationship; it appears to be well adapted to the situations in which the interests of the intendant and the principal are converging, unlike the Agency theory which recognizes that the interests of $\mathrm{E}$ and I can be divergent.

Both theories fail to accurately explain the E-I relationship since they give the entrepreneur a "caricaturized" image. The agent is shown with an opportunistic behaviour, while the steward is too positively described; he is always ready to submit to the interests of the company and of the Principal. We believe that these theories are insufficient to explain the dynamics of the E-BA relationship, given the specificities of the BA.

We can also enrich this theoretical part by two other theories, related to the theory of organization and to the emergent organization.

\section{Sub-section 2: The notion of emergent organization}

(l) a new approach

Unlike the theory of organizations "Organizational behaviour", which is interested in studying the entrepreneurial process from the perspective of organizational vision, where the entrepreneurial behaviour for an organization is as important and significant as for an individual. With this in mind, studying entrepreneurship means studying activities that could lead someone to create a new entity, rather than activities related to the development. 


\section{(m) The organization formation}

E. Learned (1992) suggests a procedural model of the organization creation, that tries to highlight what is happening before the existence of the organization.

It has three dimensions of the creation process leading to the decision of the creation.

The propensity to create: it is the result of a combination of psychological traits and of professional history, which makes individuals more likely than others to attempt the creation a business.

The intention to create: having that propensity to create, they may encounter situations that trigger the intention to create the organization.

The structuring of the information : this step is about finding meaningful information in the environment, and deducing the tasks to run in order to create the organization.

\section{(n) the characteristics of emerging organizations:}

Jérôme Katz and William B. Gartner seek the answer of what is an organization, they relied on the definition of McKelvey in his book "Organizational Systematics": "an organization is a completed system of activity containing one or more conditionally independent and finished, having ratios of input-output resources, in order to survive in environments that impose specific constraints".

To better understand this definition, which seems to integrate abstract concepts, we will highlight four main properties that characterize a complete organization. Two of which are conflicting: the intent and the Exchange, while the two others are structural : resources and limits.

This model has finally shown that it is impossible to create without a creator... Shaver and Scott (1991) support the importance of the entrepreneur's role as an initiator of the process of the company's creation.

\section{Theoretical part - conclusion:}

All these outlined models and theories focus their studies on the intention of creation, which implies the organization's pre-launch stage, with no emphasis on the results of the entrepreneur and the performance of his organization.

However, we could compare a successful business to a baby who does not cease to evolve, to grow his knowledge and to increase his competence from his birth day, according to the environment variants in which the company operates. 


\section{Section 3: Entrepreneurial Finance and the financing of Start-ups}

The purpose of our paper is to present and analyse the entrepreneurial finance as an research field, arousing the interest of financiers, in order to explain the modalities of financing Start-UP companies.

\section{SUB-SECTION 1: ENTREPRENEURIAL FINANCE}

From the point of view of researchers in finance, according to Denis (2004), entrepreneurship has long been regarded as a totally separate field of corporate finance, this has been said based on the assumption that the issues encountered in entrepreneurial finance are sufficiently different from those encountered in companies.

Many publications have focused on the issues of the IPO start-ups. For the sake of Comparison, little work has been spent on the funding of the very beginnings of the entrepreneurial venture (which contributions do entrepreneurs start with? are they somehow differences depending on their training and their professional experience?). The lack of work dedicated to business angels is also deplored (Denis, 2004).

"Thus, the entrepreneurial perspective covers a whole range of issues that cross the financial risk with the entrepreneurial risk, when it comes to financing projects"; therefore, this implies the interest in the financial dimension of the entrepreneurial project.

Studies concerning the financing choice made by the contractor are very few. Ueda (2002) aimed to modelize the choice of the entrepreneur between banks and venture capital ; this shows that this choice is notably influenced by the contractor's fear that his project would be "stolen".

\section{FINANCING START-UP COMPANIES}

The Internal financing of these start-ups consists mainly in contributions from the founder and his family. This funding source is limited and is often insufficient. Start-UP companies must use external financing during the early stages of the innovative project implementation. However, even if these StartUPs are considered to be businesses with strong growth potential, they are also characterized as highly risked.

These features constitute an important challenge for entrepreneurs during their research on the necessary fundings to develop their activity. Their business start-up status, associated with the innovative nature of their project, reinforces the traditional problems of asymmetric information with external financing providers (Hall [2002], Barnes and al.) [2003]).

Start-Ups may then have access to external funding through venture capital firms or natural persons. These specialized financial intermediaries are raising funds from investors (banks, insurance companies, pension funds, etc.). 
In conjunction with the contribution of capital and financial expertise, the venture capital firm provides aid and advice to businesses on recruitment, marketing, and relationship with customers and suppliers. This double competence allows the venture capital company to select projects before investing, and to monitor their development afterward (Lerner [1995], Kaplan and Stromberg [2001]).

4According to their stage of development, Start-Ups, more or less, easily use financing through bank loans or equity investments. The creation phase of the company, which predates the products marketing, can hardly be funded by bank loans. The young sprouts cannot get financed from external investors other than venture capital firms.

Moreover, at this initiating stage, public authorities intervene by allocating public aids (under the form of direct subsidies, refundable ZeroInterest Loans etc...).

5In the later stages of development (product marketing and firm expansion), the intervention of a venture capitalist turns out to be crucial, both in terms of financing and of advice.

6Thus, the specific characteristics of each firm are conditioning both the firm's external financing needs and the available offers.

\section{- Sub - section 2 : STARTUP financing forms}

For Modigliani and Miller [1958], in the absence of tax considerations [1963], equity and debt financing are equivalent. However, the existence of information asymmetries between the Principal (the provider of capital) and the Agent (the entrepreneur) increases the cost of external financing and leads to the existence of an optimal capital structure (Jensen and Meckling [1976], Fama) ([1980], Myers and Majluf [1984]).

These theoretical studies notably focus on the issue of sharing the financial rights and the attribution of control rights. Sharing financial securities must ensure a sufficient compensation to the Venture Capital and to the head of the firm, in order to promote the necessary involvement of everyone for the project to success.

13Other articles highlight the interest of the convertible debt use (Dewatripontand al. [2003]) and of the sequential funding (Bergmann and Hege [1998]). Financing through steps allows the venture capital company to threaten the company in order to stop funding the next step, in case the intermediate results are insufficient.

However, this constraint promotes short term behaviour from the leader, that might get him to brighten the balance sheet in order to avoid funding cancelation. The use of convertible debt into shares may limit this type of behaviour from the firm. 
From An empirical point of view, Kaplan and Stromberg [2002] detailed financial instruments and control instruments in effectively concluded contracts in the United States, between venture capital companies and businesses they provide financing to. The authors point out that venture capital financing most often takes place through convertible bonds.

15 Another recent plan of the theoretical literature on financing start-ups has treated the issue of the alternative between different financing modes. Thus, Bernhardt and Krasa [2004] have studied the impact of competition between capital providers on the acquisition of information and financing contracts.

Their model is characterized by the presence of four balances, representing an external funding $i$ ) by banks, ii) by venture capital companies, iii) by the Business Angels, iv) or even the absence of external funding. For its part, Landier [2004] explains the financing mode which prevails in a field by the cost of the bankruptcy, to the benefit of the entrepreneur, in case he has to look for a work.

On the other hand, venture capital expertise allows him to perfectly identify the risk of creating the company. However, because of its expertise, the Venture Capital company could threaten the company to "steal" its project and undertake it in its place.

This assumption of expropriation is based on the results obtained by Hellmann and Puri [2002] on the Silicon Valley start-up data. They have highlighted that the companies that are financed by venture capital are more likely prone to the replacement of the company's creator by an external CEO.

16Empirically, the analysis of the start-ups' financing is facing difficulties to access individual data, which is deemed strategic by both companies and venture capital firms that finance them. Schafer and al. [2004] use individual data collected from an organisation that refinances banks and private investors, who finance their own innovative companies in the form of loans or equity.

\section{General conclusion:}

In conclusion, the role of specialized companies in helping the creation of businesses is essential for the firms facing a strong problem of information asymmetry; providers of traditional capitals, such as banks, do not have the means to assess the quality of the innovative projects.

In addition, the entrepreneurial finance, through venture capital firms, can offer funding to firms which expertise has enabled to be identified as having a probability of sufficient success.

The specialization and the capacity-building of expertise regarding traditional banking intermediaries could encourage the innovation funding by reducing the severity of the information asymmetry issue they are facing. This 
fundamental aspect, that the financier cannot overlook, underlines the intervention limits of traditional banks in financing such projects.

\section{References:}

1. Rousseau, F. L. et Vallerand, R. J. (2003). Le rôle de la passion dans le bien-être subjectif des ainés. Revue québécoise de psychologie, 24(3), 197-211.

2. Alain FAYOLLE, (2002) in the field of entrepreneurship in the study of the entrepreneurial process: some ideas and avenues of research, 6th international conference francophone SMEs - October 2002 - HEC Montreal, Canada.

3. GARNER W.B. (1985), A framework for describing the phenomenon of new venture creation, Academy of Management Review, 10, p 696-706.

4. Bygrave and Hofer W.D. Bygrave, C.W. Hofer (1991), Theorizing about entrepreneurship, Entrepreneurship theory and practice, Winter, 1991, p13-12.

5. Filion LJ (1997), the field of entrepreneurship: history, development trends, notebook search no. 91.01, HEC Montréal, 1997, 36 pages.

6. Barneto P., Gregorio G (2007), Finance - Manual and applications, Dunod.

7. Gumpert D. E. (2002), Burn your business plan ! What investors really want entrepreneurs from, Needham, my: Lauson Publishing Co.

8. Jobard J.P.., c. Vailhen., 'Finance', in the Duff a. (ED) (1999), encyclopedia of management and dumanagement, Dalloz, 1999, p.613 - 626.

9. Verstraete T. (2002), proposal of a framework for entrepreneurship research, Editions of the ADREG, December, (http://www.editionsadreg.net)).

10. Verstraete T., Fayolle, A. (2005) , " paradigms and entrepreneurship" Journal of entrepreneurship, vol. 4, no. 1, 2005, (http://www.revue-entrepreneuriat.com). 